\title{
Gamma Ray and Radon Anomalies in Northern Taiwan as a Possible Preearthquake Indicator around the Plate Boundary
}

\author{
Ching-Chou Fu $\left(\mathbb{D},{ }^{1}\right.$ Lou-Chuang Lee, ${ }^{1}$ Tsanyao Frank Yang, ${ }^{2 \dagger}$ Cheng-Horng Lin, ${ }^{1}$ \\ Cheng-Hong Chen, ${ }^{2}$ Vivek Walia, ${ }^{3}$ Tsung-Kwei Liu, ${ }^{2}$ Dimitar Ouzounov, ${ }^{4}$ \\ Gioacchino Giuliani, ${ }^{5}$ Tzu-Hua Lai, ${ }^{6}$ and Peng-Kang Wang ${ }^{1}$ \\ ${ }^{1}$ Institute of Earth Sciences, Academia Sinica, Taiwan \\ ${ }^{2}$ Department of Geosciences, National Taiwan University, Taiwan \\ ${ }^{3}$ National Center for Research on Earthquake Engineering, NARL, Taiwan \\ ${ }^{4}$ Chapman University, One University Drive, Orange, CA, USA \\ ${ }^{5}$ Permanent Foundation G. Giuliani, L'Aquila, Italy \\ ${ }^{6}$ Central Geological Survey, MOEA, Taiwan \\ ${ }^{\dagger}$ Deceased \\ Correspondence should be addressed to Ching-Chou Fu; ccfu@earth.sinica.edu.tw
}

Received 15 March 2019; Revised 11 June 2019; Accepted 23 June 2019; Published 4 September 2019

Guest Editor: Yunpeng Wang

Copyright ( 2019 Ching-Chou Fu et al. This is an open access article distributed under the Creative Commons Attribution License, which permits unrestricted use, distribution, and reproduction in any medium, provided the original work is properly cited.

\begin{abstract}
Taiwan is tectonically situated in an oblique collision zone between the Philippine Sea Plate (PSP) and the Eurasian Plate (EP) Continuous observations of gamma rays at the Yangmingshan (YMSG) station and soil radon at the Tapingti (TPT) station were recorded in the volcanic area and around a major fault zone, respectively, in Taiwan for seismic studies. A number of anomalous high gamma ray counts and radon concentrations at certain times were found. It is noted that significant increases of soil radon concentrations were observed and followed by the increase in gamma rays a few days to a few weeks before earthquakes that occurred in northeastern Taiwan. Earthquakes such as these are usually related to the subduction of the PSP beneath the EP to the north along the subduction zone in northern Taiwan (e.g., $M_{\mathrm{L}}=6.4$, April 20, 2015). It is suggested that the preseismic activity may be associated with slow geodynamic processes at the subduction interface, leading to the PSP movement triggering radon enhancements at the TPT station. Furthermore, the further movement of the PSP might be blocked by the EP, with the accumulated elastic stress resulting in the increase of gamma rays due to the increase in porosity and fractures below the YMSG station. The continuous monitoring of the multiple parameters can improve the understanding of the relationship between the observed radon and gamma ray variations and the regional crustal stress/strain in north and northeastern Taiwan.
\end{abstract}

\section{Introduction}

The island of Taiwan is the result of an oblique collision zone, with a convergence rate of about $8 \mathrm{~cm} / \mathrm{yr}$ in the direction of $306^{\circ}$ [1], between the Philippine Sea Plate (PSP) and the Eurasian Plate (EP) (Figure 1). In the south, the EP underthrusts the PSP to the east along the Manila trench, while to the north, the PSP subducts beneath the EP along the Ryukyu Arc and induces spreading of the Okinawa Trough. The interaction of these two plates generates many earthquakes. The Plio-Pleistocene volcanism of the Tatun Volcano Group
(TVG) is situated both at the northern tip of Taiwan and the western tip of the Ryukyu Arc, which might be associated with the opening of the Okinawa Trough and the postcollisional extension [2-4]. According to previous radiometric dating investigations, two major eruptions of the TVG occurred at $2.5-2.8 \mathrm{Ma}$ and $0.8-0.2 \mathrm{Ma}$ [5-10]. Juang [11] considered the TVG extinct because the last major volcanism occurred from 0.8 to $0.2 \mathrm{BP}$. Also, Chen and Shen [12] reviewed some records of historical eruptions in northern Taiwan and suggested that volcanism of the TVG has ended. 


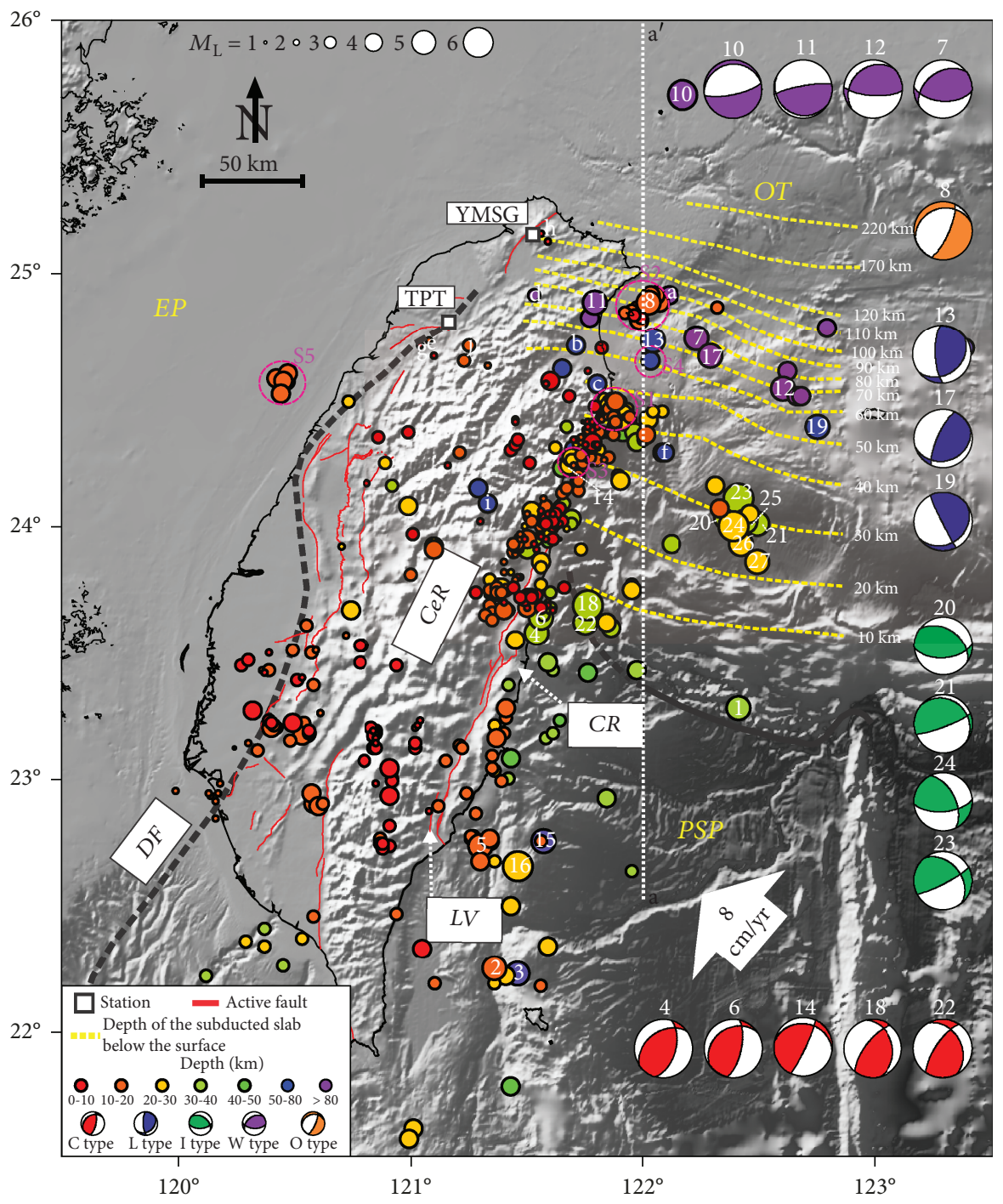

Figure 1: The simplified sketch of the regional map and principal tectonic structures around Taiwan shows that the Philippine Sea Plate (PSP) is moving northwest at $8 \mathrm{~cm} / \mathrm{yr}$ towards the Eurasia Plate (EP). The circle symbols represent the earthquake epicenter with the focal depths corresponding to different colors from July 1, 2014, to June 1, 2015. The open square represents the location of the YMSG gamma ray station and the TPT radon station. The red lines indicate the active fault proposed by the Central Geological Survey of Taiwan [66]. Seismic events with magnitudes larger than five and some specific earthquakes are labeled and listed in Table 2. The yellow dashed lines indicate the isodepth contours between 10 and $220 \mathrm{~km}$. OT = Okinawa Trough; $\mathrm{CeR}=$ central range; $\mathrm{CR}=$ costal range; $\mathrm{LV}=\mathrm{Longitudinal}$ Valley; DF = deformation front.

However, Yang et al. $[13,14]$ and Ohba et al. [15] suggested that a magma chamber might still exist beneath the TVG area based on a high ${ }^{3} \mathrm{He} /{ }^{4} \mathrm{He}$ ratio from fumarolic gas and the high $\mathrm{CO}_{2} / \mathrm{H}_{2} \mathrm{O}$ ratio of magmatic components. Konstantinou et al. [16] and Wen et al. [17] proposed that magma chambers might exist at depths of 7 to $20 \mathrm{~km}$ as indicated by the seismicity characteristics and attenuation structure. Lin [18] proposed the presence of a deep magma reservoir in the lower crust using S-wave shadow and Pwave delay. In recent years, there have been an increasing number of studies in the TVG area focusing on geochemical investigations and monitoring of the gas compositions, soil flux, and hot spring water [19-27] and seismological and geological research, such as seismicity, seismic variations, and ground deformation $[16,28-33]$, which has provided more evidences that the TVG could still be active. As the TVG is located close to the Taipei metropolis and two nuclear power plants, long-term monitoring is necessary for providing possible early warnings of volcano-related hazards and major earthquakes.

Radon $\left({ }^{222} \mathrm{Rn}\right)$ is the major radioactive gas in this volcanic area. To investigate volcanic activity in the volcanic areas, the monitoring of radon level variations has been considered as a useful tool $[20,27,34-38]$. This research provides another way to record gamma rays related to radon gas emission from underground towards the surface. The anomalous gamma rays may be associated with the radioactive material released during crustal fracturing due to plate motions and geodynamic processes [39]. The objective of this paper is to assess the feasibility of using the gamma ray method to 


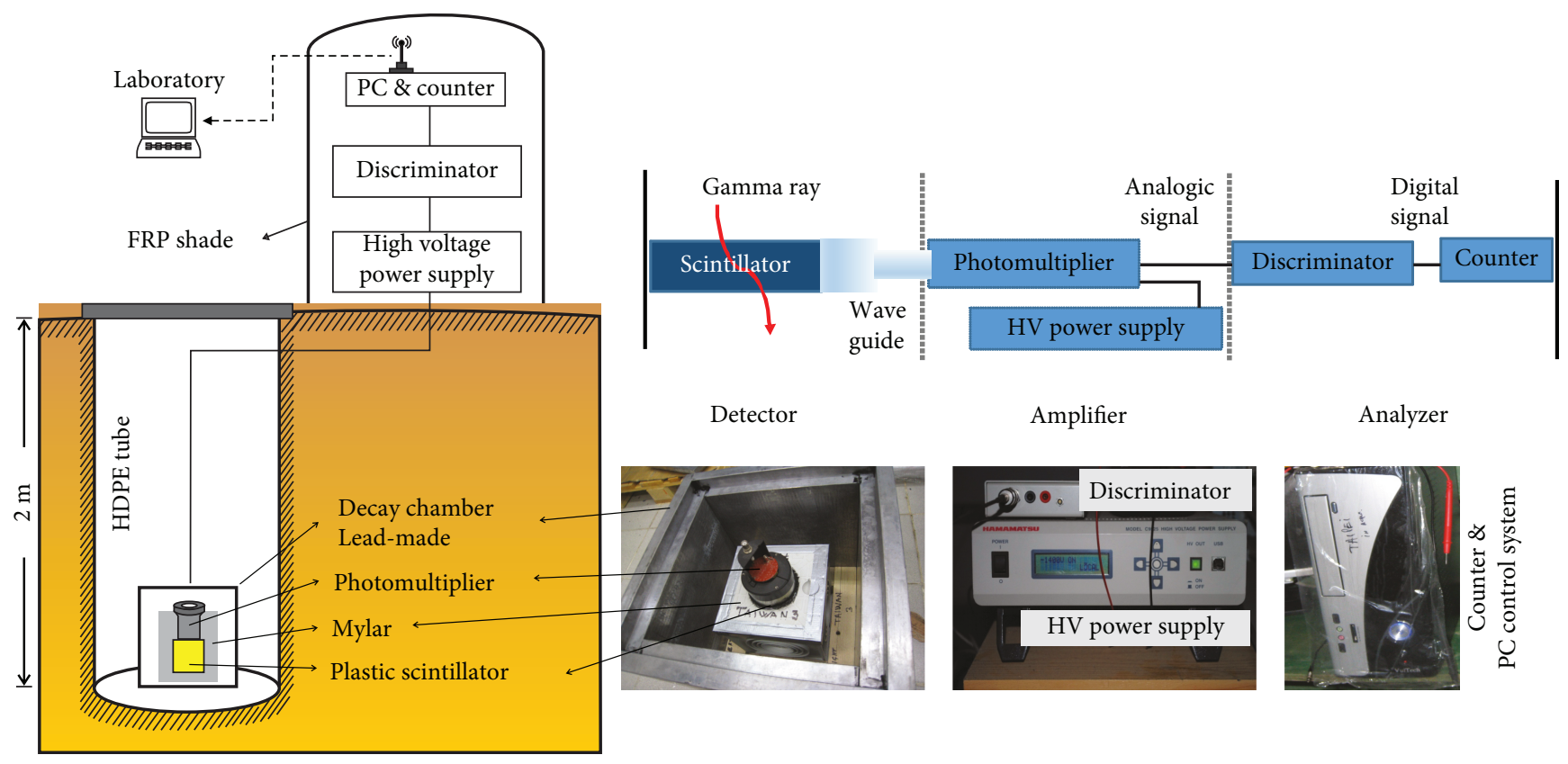

(a)

(b)

FIgURE 2: (a) Schematic of the gamma ray sensor installation in the YMSG monitoring station. (b) The block diagram and pictures of the gamma sensor assembly.

monitor seismic and volcanic activities in northern Taiwan. The location of the gamma ray station in the Yangmingshan (YMSG) area near the Taiwan Volcano Observatory at Tatun (TVO) was chosen for the first gamma ray observations in a volcanic region of Taiwan. In this study, gamma rays were continually monitored from July 1, 2014, to June 1, 2015. The potential for using a gamma ray anomaly as the possible precursor of earthquake and/or volcanic activity in northern Taiwan was further evaluated on this basis. In order to evaluate the accuracy of possible anomalous gamma ray changes, the radon variations at the Tapingti (TPT) station were chosen for comparison, being located about $70 \mathrm{~km}$ southwest of the YMSG gamma ray station.

\section{Methodology}

Radon is a naturally radioactive noble gas, widely distributed in various places throughout the Earth's crust. Radon is generated in the uranium decay series. The emission of energy from radon can be in the form of alpha or beta particles and gamma rays. Thus, gamma radiation can be used for indirectly determining the radon concentration.

The YMSG monitoring station is equipped with a gamma ray spectrometer with a scintillation counter inside a container made of $7 \mathrm{~cm}$ thick lead, inserted in a High-Density Polyethylene (HDPE) tube at a depth of 2 meters (Figure 2). The NE110 gamma ray is a plastic scintillator with a size of $400 \mathrm{~mm} \times 400 \mathrm{~mm} \times 400 \mathrm{~mm}$, connected to photomultipliers with a diameter of $7.6 \mathrm{~cm}$. Any cosmic gamma rays from atmospheric sources can be prevented from reaching the scintillation counter by using the lead box as a decay chamber to provide passive shielding. When radon gas migrates into the lead box, specific gamma rays may be emitted from
${ }^{214} \mathrm{~Pb}$ and ${ }^{214} \mathrm{Bi}$ as decay products in the uranium decay series after radon. The energy of the window channel is limited within the range of 250 to $700 \mathrm{keV}$, which includes the response of gamma rays at $351 \mathrm{keV}$ for ${ }^{214} \mathrm{~Pb}$ and $609 \mathrm{keV}$ for ${ }^{214} \mathrm{Bi}$. The pulse of the chosen energy signal is converted to generate electron currents by the photomultipliers, and then, they are recorded by the discriminator and computer. The description of a similar operation and setting was described in detail by Giuliani et al. [40] and Fu et al. [39]. Meteorological records (e.g., atmospheric pressure, temperature, humidity, and hourly precipitation) are available from a meteorological station of the Central Weather Bureau (CWB) of Taiwan, which is located at a distance of $1 \mathrm{~km}$ from the YMSG gamma ray station. Measurements are recorded once every hour and immediately wirelessly transmitted to the server at the Institute of Earth Sciences, Academia Sinica, from the gamma ray and meteorological stations.

The methodology of the operation at the TPT radon station follows that as described in detail by $\mathrm{Fu}$ et al. [41]. Seismic data were acquired from the earthquake catalogs of the CWB. In total, there were 482 seismic events with magnitudes $\left(M_{\mathrm{L}}\right)$ ranging from 1.4 to 6.7 during the monitoring period in the Taiwan area.

\section{Results}

The gamma ray results along with meteorological data recorded on an hourly basis at the YMSG station were presented in Figure 3. The gamma counting rate was observed to vary from 589 to $25,020 \mathrm{cph}$ (counts per hour) with an average value of $3,172 \mathrm{cph}$. During the same period, atmospheric pressure $\left(P_{\mathrm{atm}}\right)$ varies from 924 to $958 \mathrm{mbar}$, atmospheric humidity $\left(H_{\text {atm }}\right)$ from 31 to $100 \%$, and atmospheric 

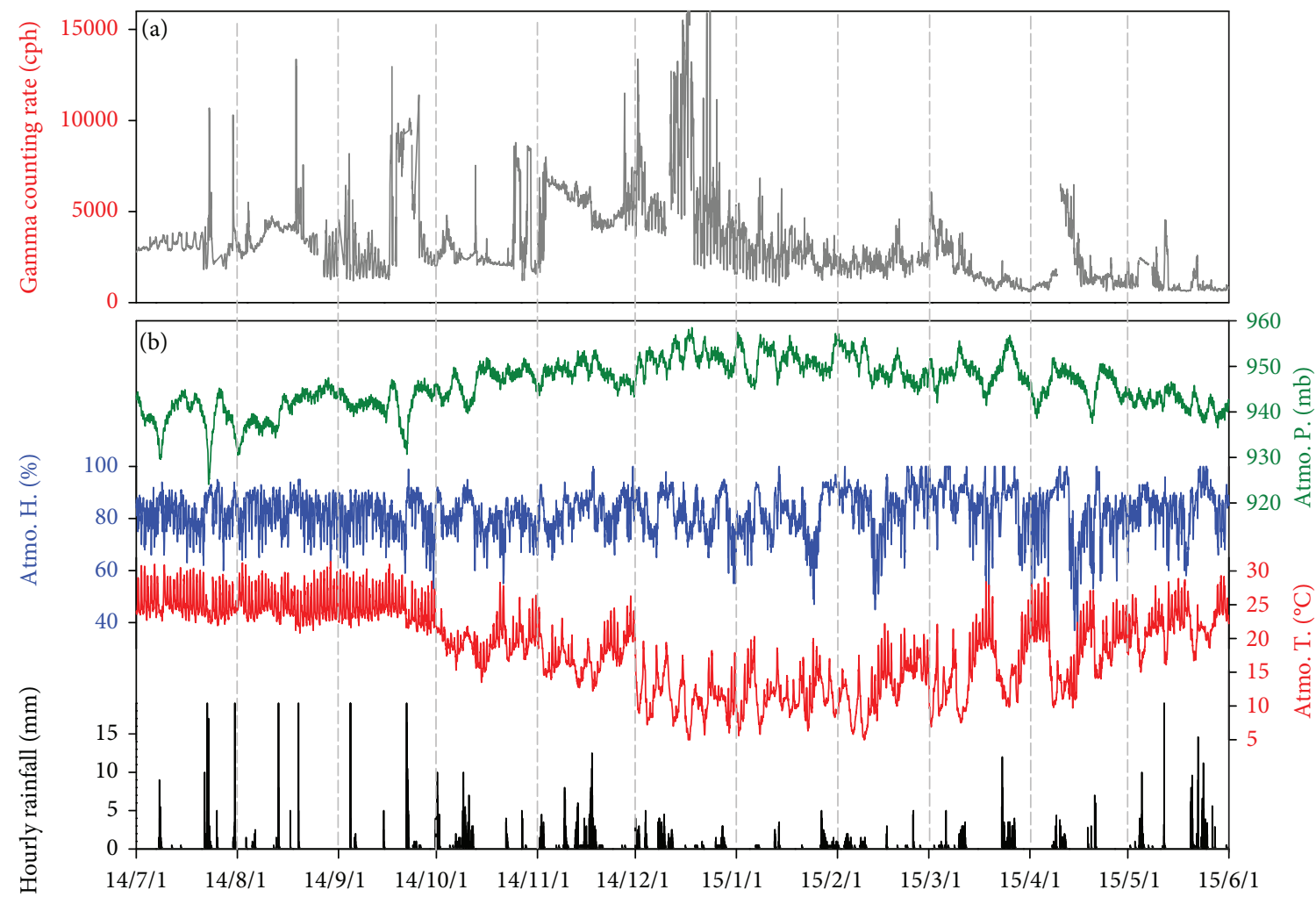

FIgURE 3: Temporal variations of gamma rays at the YMSG station (a) and (b) atmospheric data, including atmospheric pressure (green), humidity (blue), temperature (red), and hourly rainfall (black) (b) from July 1, 2014, to June 1, 2015.

temperature $\left(T_{\mathrm{atm}}\right)$ from 4.4 to $31.4^{\circ} \mathrm{C}$, with the mean value of $946 \mathrm{mbar}, 82.3 \%$, and $18.5^{\circ} \mathrm{C}$, respectively. Temporal variations of the meteorological factors are not evident. After the initial adjustment for the detector, the gamma counting rate decreases to a low background value of about 1,100 cph for the period from March 15 to June 1, 2015. Substantial increases in the gamma counting rate were observed periodically over the observation period. A wide range of radon gas concentrations in the soil at the TPT station from 7,337 to $31,931 \mathrm{~Bq} / \mathrm{m}^{3}$ with an average value of $15,589 \mathrm{~Bq} / \mathrm{m}^{3}$ was observed and is shown in Figure 4.

\section{Discussion}

4.1. The Influence of Meteorological Parameters. Some earlier investigations have revealed that changes in gamma rays may be affected by meteorological factors, such as atmospheric pressure, humidity, temperature, and precipitation [39, 4246]. Therefore, it is necessary for meteorological effects to be taken into consideration when analyzing gamma ray results. Fu et al. [39] proposed that the air temperature had significant influence on the gamma ray measurements in eastern Taiwan due to a high correlation coefficient between the air temperature and the presence of the gamma ray. However, the influences of meteorological pressure, humidity, and temperature on gamma ray variations were relatively small due to the extremely low correlation coefficients of $0.0178,0.0022$, and 0.0139 , respectively, for the study period (Table 1). These low correlation coefficients indicated that the gamma variations at the YMSG station are not mainly controlled by meteorological parameters.

Fu et al. [39] presumed that the significant decrease in temperature cause reduced sensitivity of electrical sensors. In this study, the marginal effect of atmospheric temperature at the YMSG station, which is situated in a mountainous area (approximately $700 \mathrm{~m}$ a.s.l.), may be associated with the relatively small fluctuation of underground temperatures because of the tree shade. To evaluate this possibility, the in situ temperature measurement with a gamma sensor in the monitoring station should be considered in the future.

The temporary, abrupt increase in gamma ray was observed periodically, which may be related to heavy rainfall or precipitation accumulation. This sudden increase in the gamma dose was usually followed by a rapid return to background levels within a few hours after the rain stopped. These observations suggest that short-term (few hours) fluctuations in the rise of gamma rays were partially influenced by a heavy precipitation event, as has been similarly described before [43, 47-49].

For the TPT station, Fu et al. [41] have pointed out that the effects of meteorological parameters on soil radon concentration were insignificant. Therefore, meteorological effects were not taken into consideration during the duration of soil radon concentration anomalies at the TPT station.

4.2. The Relationship between Gamma Ray and Radon Variations and Seismicity. The time series gamma ray data from YMSG was plotted with seismic events, rainfall records, and the radon concentrations of TPT for a period from 


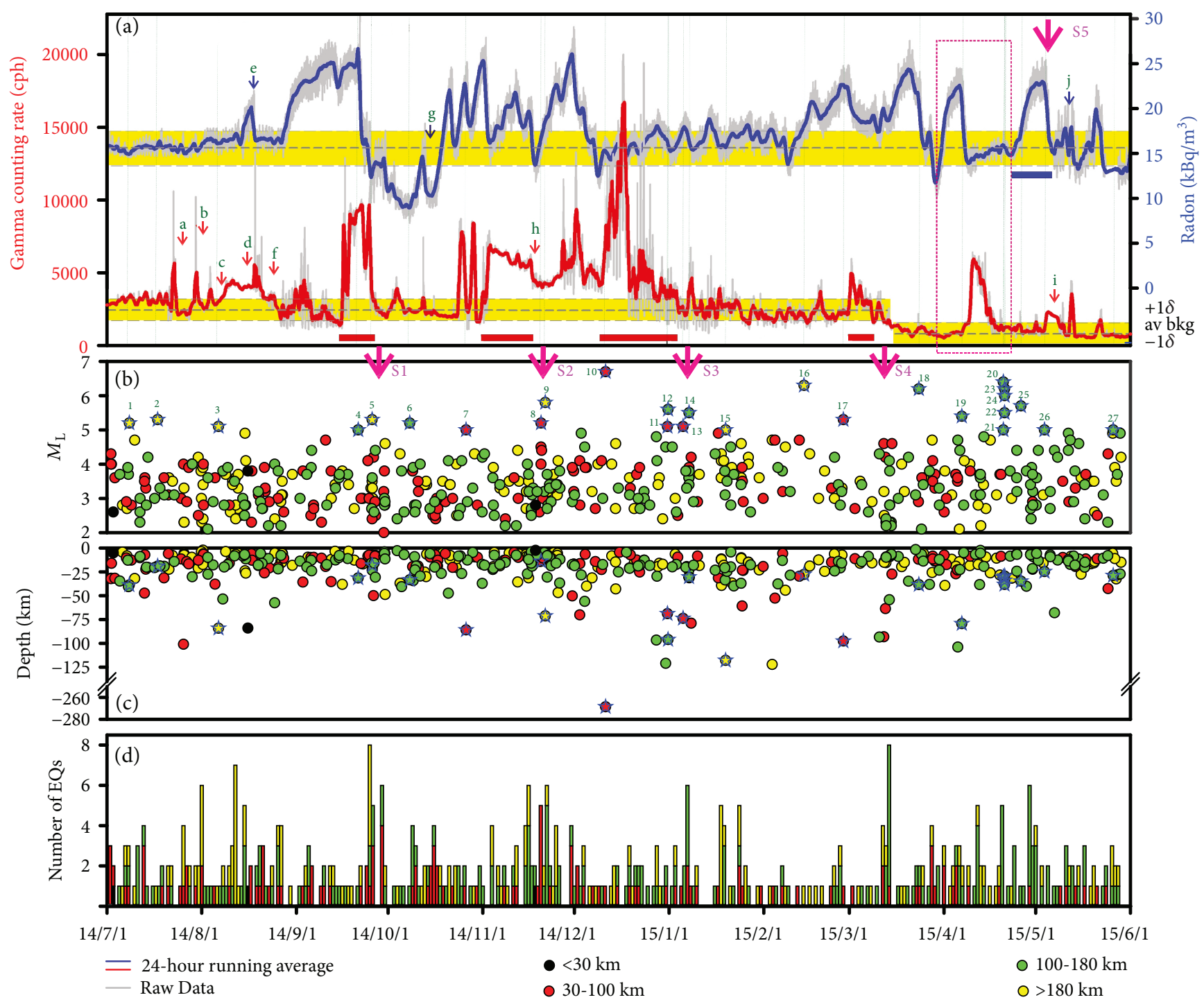

Figure 4: The temporal variations of (a) radon and gamma rays from July 1, 2014, to June 1, 2015. Blue and red lines indicate the 24-hour running averages of radon and gamma ray data, respectively; grey lines represent the raw data. Horizontal dashed lines indicate the annual averages of the observed results, and the anomalous threshold value $( \pm 1 \sigma)$ is included with the yellow bar. The magnitude and depth of earthquakes are plotted in (b) and (c), respectively. The circle symbols in different colors indicate that the epicenter distance of the earthquake to YMSG station was <30 km (black), 30 to $100 \mathrm{~km}$ (red), 100 to $180 \mathrm{~km}$ (green), and $>180 \mathrm{~km}$ (yellow). Red and blue arrows indicate the specific seismic events. The accumulated number of earthquakes at different distances is also shown as a histogram (d). One specific period of time marked by the dashed rectangle is enlarged in Figure 5.

June 1, 2014, to June 1, 2015, in Figure 4. Many substantial increases in gamma ray and radon concentrations were recorded periodically, and slight diurnal variations were also recorded as shown by the grey line in Figure 4(a). The 24hour running average of the gamma counting rate and radon concentrations are shown as red and blue lines, respectively, in Figure 4(a) to distinguish their background values. The threshold values were determined using the mean value plus one standard deviation as shown by the grey dashed lines.

The magnitude and depth of the earthquakes were plotted in Figures 4(b) and 4(c), respectively. The seismic event data included the magnitude and depth of the earthquakes, which are sorted by the distances between the YMSG station and the epicenter of the earthquakes for discussing the spatial distribution of the seismic events. The earthquakes at different distances are plotted in different colors as black, red, green, and yellow circles for distances less than $30 \mathrm{~km}, 30$ to $100 \mathrm{~km}, 100$ to $180 \mathrm{~km}$, and greater than $180 \mathrm{~km}$, respectively. To show the intensity of seismic activity, the accumulated numbers of earthquakes at different distances are also included (Figure 4(d)). The distribution of some specific seismic events is marked in Figure 1, including earthquakes having a magnitude $\geq 5$, an earthquake swarm, and a local earthquake with an epicentral distance less than $30 \mathrm{~km}$ to the monitoring station, and the catalog of those earthquakes is listed in Table 2.

The temporal variation of gamma rays and radon shows similar patterns, whereas some high gamma ray 
TABLE 1: Correlations between gamma ray variations and meteorological parameters, including atmospheric pressure $\left(P_{\mathrm{atm}}\right)$, temperature $\left(T_{\mathrm{atm}}\right)$, and humidity $\left(H_{\mathrm{atm}}\right)$ during different time periods.

\begin{tabular}{lccc}
\hline & $\gamma$-Rays \& $P_{\text {atm }}$ & $\gamma$-Rays \& $T_{\text {atm }}$ & $\gamma$-Rays \& $H_{\text {atm }}$ \\
\hline $2014 / 07$ & $0.2306^{*}$ & 0.0339 & 0.0064 \\
$2014 / 08$ & 0.1056 & 0.0585 & 0.0504 \\
$2014 / 09$ & 0.1105 & 0.0253 & 0.0091 \\
$2014 / 10$ & 0.021 & 0.0095 & 0.0041 \\
$2014 / 11$ & 0.0316 & 0.0124 & 0.0267 \\
$2014 / 12$ & 0.249 & 0.0171 & 0.1124 \\
$2015 / 01$ & 0.1932 & 0.0285 & 0.3428 \\
$2015 / 02$ & 0.0082 & 0.0053 & 0.0405 \\
$2015 / 03$ & 0.0004 & 0.1215 & 0.3099 \\
$2015 / 04$ & 0.2202 & 0.0326 & 0.3606 \\
$2015 / 05$ & 0.1838 & 0.02 & 0.3988 \\
\hline
\end{tabular}

${ }^{*} R$-squared values.

and radon concentration peaks in the entire spectrum can also be observed. In addition, it is noted that the increase of soil radon concentrations usually occurred before the change in gamma ray counts. For calculating the anomalies, the anomalous thresholds are found using the average value plus one to three standard deviations [50-52]. In this study, the precursory anomalies were determined as when the running average exceeds one standard deviation, which then can be used to correlate with seismic events (Figure 4 and Table 2).

A comparison of gamma ray data and earthquakes detected by the CWB over the monitoring period indicates that the presence of gamma ray anomalies was quite often accompanied by seismic activity, except for fourteen of twenty-seven marked earthquakes with magnitudes $\geq 5$ ( 1 , $2,3,4,5,9,14,15,16,18,19,22,25$, and 26 in Figure 1 and Table 2). The Events 14 and 22 are considered to be triggered by an earlier earthquake series due to different focal mechanisms and will not be further discussed. Some shortterm impulsive gamma ray increases were also recorded with peak values greater than the threshold value before the Events a, b, c, d, f, h, and i. It is noted that the magnitude of those events is smaller than five with a hypocenter depth deeper than $40 \mathrm{~km}$ or an epicenter distance of $<30 \mathrm{~km}$ to the monitoring station. In addition, four significant longterm increases of the gamma ray were also observed from September 15 to 25, 2014, from November 2 to 17, 2014, from December 11, 2014, to January 3, 2015, and from February 28 to March 10, 2015. These anomalies could not be correlated with any significant earthquake, except for the third period. However, the accumulated number of earthquakes displays unusually high seismic activity, such as S1, S2, S3, and S4, which may be related to gamma ray anomaly periods as shown by the red bars in Figure 4(a). These four seismic swarms occurred at a depth of 4 to $50 \mathrm{~km}$ from September 26 to 29,2014 , with magnitude 2.0 to 4.4 for S1; at a depth of 4.9 to $71 \mathrm{~km}$ from November 20 to 22, 2014, with magnitude 2.7 to 5.2 for S2; at a depth of 23 to $31 \mathrm{~km}$ on January 7, 2015, with magnitude 3.4 to 5.5 for S3; and at a depth of 6 to $93 \mathrm{~km}$ from March 12 to 14, 2015, with magnitude 2.2 to 4.6 for S4, respectively. The distance between the epicenters of these four seismic swarms and the YMSG station was approximately 50 to $130 \mathrm{~km}$.

Similarly, the presence of radon anomalies at the TPT station could also be connected with marked seismic events with a magnitude $\geq 5$, except for the Events $1,2,3,5,9,11$, $12,13,14,15,16,19,22,25$, and 26 in Figure 1 and two local earthquakes (Events e and g). It is noted that the soil radon obviously increased during April 24 to May 3, 2015, and there was a sudden drop in radon concentrations on May 3 followed by an earthquake swarm (S5), which occurred at depths of 11-14 km from May 1 to 15, 2015, with magnitudes 4.2 to 4.9 . The distance was approximately $70 \mathrm{~km}$ from the epicenter of the earthquake swarm (S5) to the TPT station as shown in Figure 1.

Each gamma ray and radon anomaly is assigned to a definite earthquake and could only be correlated with the precursory anomalous increase a few days to a few weeks before the event occurrence. Each precursory time was illustrated in Figure 5, and the precursory catalog of each seismic event is listed in Table 2.

Figure 5 shows an example for the preearthquake anomalous period of gamma ray and radon results from March 29 to April 22, 2015, before Event 20. Here, $\Delta T_{\text {Gamma }}$ and $\Delta T_{\text {Radon }}$ are the time differences between the start time of an anomaly and the earthquake event for the gamma ray and radon anomalies, respectively. In Figure 5, the radon at TPT rose progressively until April 7, 2015, with a peak value of about $23 \mathrm{kBq} / \mathrm{m}^{3}$. A temporal decrease in radon occurred from April 7 to 9, 2015, and the value returned to the background value with a slight variation before Events 20 to 24 . Meanwhile, a significant increase in gamma rays at the YMSG was observed from April 7 to 11, 2015, with a peak value of $6,000 \mathrm{cph}$. Then, a progressive decrease happened from April 11 to 19, 2015, when the gamma counting rates returned to the background value, followed by Events 20 to 24 , which occurred at depths of $29-38 \mathrm{~km}$ with magnitudes of 5.0 to 6.4 on April 20, 2015. The distance was approximately $150 \mathrm{~km}$ from the epicenter of the largest earthquake $\left(M_{\mathrm{L}}=6.4\right)$ to the YMSG station. In this case, the significant changes in radon and gamma ray were recorded as precursors about 21 days and 12 days, respectively, before Event 20, which occurred on April 20, 2015.

4.3. Spatial Variation of Related Earthquakes. Most large events could be linked to anomalous changes in gamma rays and radon at both stations (Table 2), and few events were only associated with one of the two anomalies. Anomalies in gamma and/or radon accompanying the relevant earthquake, which can be called the precursory event (PE), and the distribution of those events are shown in Figure 1. For YMSG, two groups of earthquakes may be recognized based on the epicenter distance.

Group A included the PE with an epicenter distance of $<30 \mathrm{~km}$ and showed anomalous gamma ray changes over a period of a few days (e.g., Event h). The PE with epicenter distances of 30 to $180 \mathrm{~km}$ showed anomalies in gamma rays 
TABLE 2: Catalog of gamma ray and radon anomalies and related earthquakes occurring in Taiwan from July 1, 2014, to June 1, 2015.

\begin{tabular}{|c|c|c|c|c|c|c|c|c|c|}
\hline No. $^{1}$ & Date & Long. $\left({ }^{\circ} \mathrm{E}\right)$ & Lat. $\left({ }^{\circ} \mathrm{N}\right)$ & Mag. $\left(M_{L}\right)$ & Depth $(\mathrm{km})$ & Distance $(\mathrm{km})$ & $\Delta T_{\text {Radon }}^{2}$ (day) & $\Delta T_{\text {Gamma }}{ }^{2}$ (day) & Type \\
\hline 1 & 2014/7/8 07:06 & 122.41 & 23.29 & 5.2 & 38.8 & 224 & None & None & - \\
\hline 2 & 2014/7/17 14:11 & 121.36 & 22.25 & 5.3 & 19.1 & 322 & None & None & - \\
\hline 3 & 2014/8/6 11:46 & 121.46 & 22.23 & 5.1 & 84.2 & 324 & None & None & - \\
\hline 4 & $2014 / 9 / 21$ 05:14 & 121.54 & 23.59 & 5 & 31.5 & 173 & 21 & None & $\mathrm{C}$ \\
\hline 5 & $2014 / 9 / 25$ 18:35 & 121.3 & 22.74 & 5.3 & 18 & 269 & None & None & - \\
\hline 6 & $2014 / 10 / 8$ 02:08 & 121.56 & 23.65 & 5.2 & 33.4 & 167 & 15 & 10 & $\mathrm{C}$ \\
\hline 7 & $2014 / 10 / 2612: 47$ & 122.23 & 24.75 & 5 & 86.0 & 81 & 8 & 3 & $\mathrm{~W}$ \\
\hline 8 & 2014/11/20 01:46 & 122.02 & 24.89 & 5.2 & 13.9 & 55 & 17 & 17 & $\mathrm{O}$ \\
\hline 9 & $2014 / 11 / 21$ 11:29 & 120.13 & 20.65 & 5.8 & 71.3 & 520 & None & None & - \\
\hline 10 & 2014/12/11 05:03 & 122.17 & 25.7 & 6.7 & 268.6 & 86 & 23 & 14 & W \\
\hline 11 & 2014/12/31 11:06 & 121.79 & 24.89 & 5.1 & 68.9 & 37 & None & 20 & W \\
\hline 12 & $2014 / 12 / 31$ 15:54 & 122.6 & 24.55 & 5.6 & 96.1 & 125 & None & 20 & $\mathrm{~W}$ \\
\hline 13 & $2015 / 1 / 513: 53$ & 122.04 & 24.74 & 5.1 & 73.8 & 67 & None & 20 & $\mathrm{~L}$ \\
\hline 14 & $2015 / 1 / 712: 48$ & 121.7 & 24.26 & 5.5 & 30.4 & 100 & None & Unknown & $\mathrm{C}$ \\
\hline 15 & 2015/1/19 11:48 & 121.57 & 22.76 & 5 & 117.9 & 265 & None & None & - \\
\hline 16 & 2015/2/14 04:06 & 121.46 & 22.66 & 6.3 & 27.8 & 276 & None & None & - \\
\hline 17 & $2015 / 2 / 2700: 50$ & 122.29 & 24.68 & 5.3 & 97.6 & 90 & 13 & 11 & $\mathrm{~L}$ \\
\hline 18 & $2015 / 3 / 23$ 18:13 & 121.76 & 23.7 & 6.2 & 38.4 & 162 & 9 & None & $\mathrm{C}$ \\
\hline 19 & 2015/4/6 19:37 & 122.75 & 24.4 & 5.4 & 79.4 & 146 & None & None & - \\
\hline 20 & 2015/4/20 09:42 & 122.37 & 24.05 & 6.4 & 30.6 & 147 & 21 & 12 & I \\
\hline 21 & 2015/4/20 09:49 & 122.49 & 24.02 & 5 & 30.7 & 157 & 21 & 12 & I \\
\hline 22 & 2015/4/20 19:20 & 121.75 & 23.63 & 5.5 & 38.3 & 170 & Unknown & Unknown & $\mathrm{C}$ \\
\hline 23 & 2015/4/20 19:45 & 122.41 & 24.12 & 6.2 & 33.9 & 143 & 21 & 12 & I \\
\hline 24 & $2015 / 4 / 2019: 59$ & 122.39 & 24.01 & 6 & 29.4 & 152 & 21 & 12 & I \\
\hline 25 & 2015/4/26 04:01 & 122.44 & 24.03 & 5.7 & 34.8 & 153 & Unknown & Unknown & - \\
\hline 26 & 2015/5/3 21:09 & 122.42 & 23.94 & 5 & 24.8 & 160 & None & None & - \\
\hline 27 & 2015/5/26 08:56 & 122.49 & 23.87 & 5 & 28.9 & 171 & 7 & 6 & I \\
\hline a & 2014/7/26 00:43 & 122.11 & 24.92 & 4 & 101 & 61 & None & 4 & - \\
\hline b & $2014 / 8 / 1 \quad 12: 38$ & 121.6 & 24.58 & 4 & 6.1 & 64 & None & 3 & - \\
\hline c & $2014 / 8 / 5$ 08:34 & 121.67 & 24.4 & 3.6 & 38 & 84 & None & 3 & 一 \\
\hline $\mathrm{d}$ & $2014 / 8 / 1602: 51$ & 121.53 & 24.92 & 3.8 & 84 & 26 & None & 7 & - \\
\hline e & 2014/8/17 06:52 & 121.04 & 24.72 & 2.3 & 6.2 & 71 & 3 & None & 一 \\
\hline $\mathrm{f}$ & $2014 / 8 / 2420: 39$ & 122.09 & 24.3 & 4 & 57.5 & 109 & None & 6 & - \\
\hline g & $2014 / 10 / 19$ 17:50 & 121.1 & 24.68 & 2.9 & 6 & 70 & 4 & None & - \\
\hline $\mathrm{h}$ & 2014/11/18 07:22 & 121.56 & 25.16 & 2.8 & 2.5 & 1 & None & 2 & - \\
\hline $\mathrm{i}$ & 2015/5/7 04:04 & 121.33 & 24.1 & 4.4 & 68 & 119 & None & 4 & - \\
\hline $\mathrm{j}$ & $2015 / 5 / 920: 32$ & 121.23 & 24.66 & 3.5 & 10 & 64 & 1 & None & - \\
\hline
\end{tabular}

${ }^{1}$ The label of relevant earthquakes marked in Figures 1 and $4 .{ }^{2}$ The time difference between the start time of an anomaly and the earthquake event. "Unknown" indicates that the relationship between an anomaly and the earthquake cannot be identified.

over several days to weeks (e.g., Events 10, 17, and 20) which was identified as Group B. It was noted that no anomaly was found when the distance of the earthquake epicenter was farther than $180 \mathrm{~km}$, such as Events 1, 2, 3, 5, 9, 15, and 16.

A diagram showing the relationship between the depth of the PE and latitude location and the seismic velocity structure along the $\mathrm{a}-\mathrm{a}^{\prime}$ line (Figure 1) is presented in Figure 6. The seismic Vp structure was found by using a local earthquake tomography model developed by $\mathrm{Wu}$ et al. [53]. The yellow dashed line indicates the possible location of the subduction zone as highlighted by contoured $\mathrm{Vp} / \mathrm{Vs}$ values higher than 1.78 [54]. It is noteworthy that a series of the PE located along the subduction zone progressively deepen to the north from $\sim 28$ to $268 \mathrm{~km}$ deep, except for Event 8 . This suggests that an anomaly of gamma rays at the YMSG station may be connected with the geodynamics process within the subduction zone in north and northeastern Taiwan.

For the TPT, Fu et al. [41] proposed that radon anomalies at the TPT station could be found when a small earthquake has hypocenters shallower than $15 \mathrm{~km}$ within $30 \mathrm{~km}$ of the monitoring station or when a large earthquake has deeper 


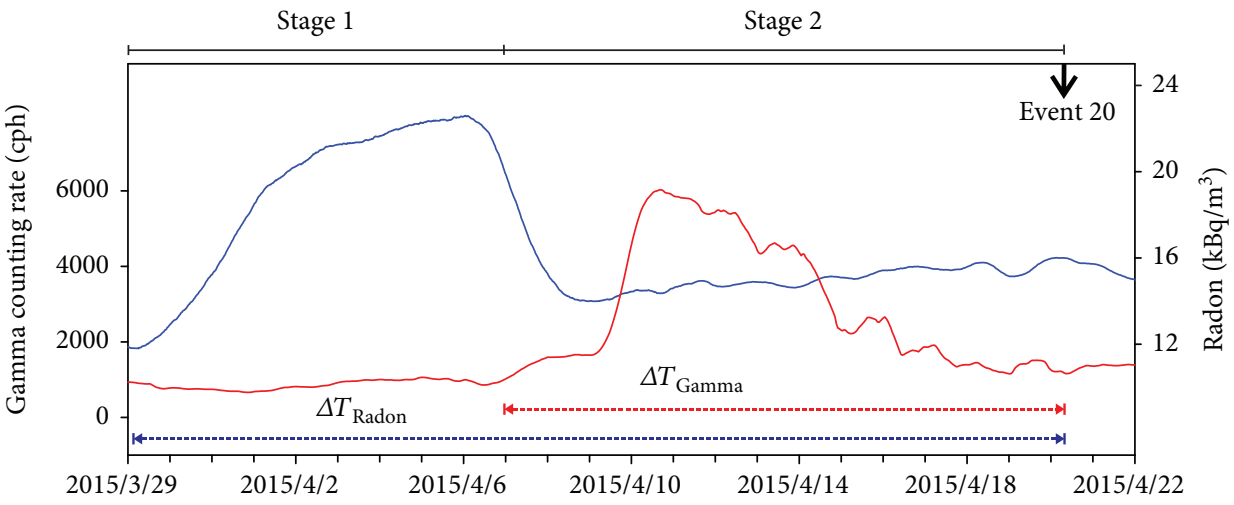

FIGURE 5: Variations of gamma ray and radon data during the period from March 29 to April 22, 2015. The preearthquake anomalous time from the gamma ray and radon results is represented by $\Delta T_{\mathrm{Gamma}}$ and $\Delta T_{\mathrm{Radon}}$, respectively, showing that a radon anomaly occurs earlier than a gamma ray anomaly with respect to an earthquake event.

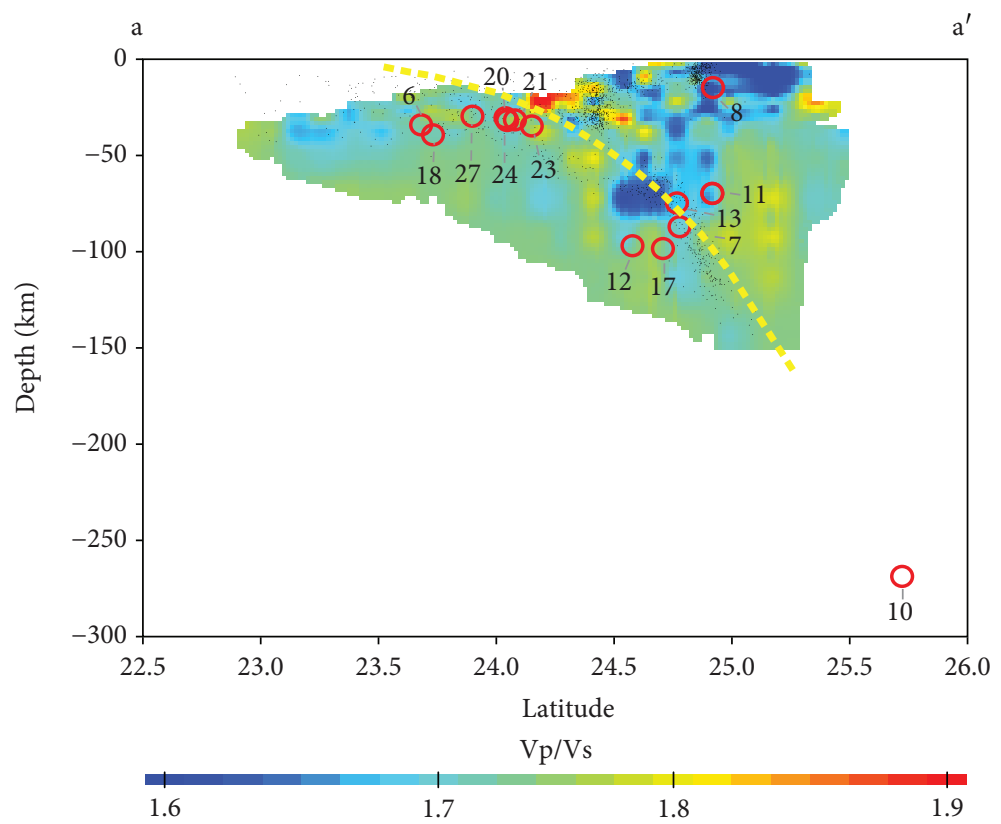

Figure 6: The seismic velocity structure transecting northern Taiwan along the a-a' line of Figure 1 is derived based on the local earthquake tomography model by Wu et al. [53]. The dots show the relocated events for $M>3$ within $\pm 5 \mathrm{~km}$ of the profile. The red open circle means that the projected earthquake with a preanomalous signal is listed in Table 2. Note that the hypocenters get deeper towards the north. The yellow dashed line indicates the subduction boundary between the PSP and the EP.

hypocenters $(>20 \mathrm{~km})$ at a greater distance $(>45 \mathrm{~km})$. In this paper, the similar anomalies in radon are also confirmed before the near- and far-field earthquakes, such as Events 6, $7,8,10,17,18,20,21,23,24,27, \mathrm{e}, \mathrm{g}$, and $\mathrm{j}$. The preearthquake activities of the far-field events may be transmitted to the region below the TPT site along the major decollement (e.g., $[55,56])$ and can facilitate the release of soil gases when squeezed. Hence, radon anomalies could be detected at the TPT station away from the large event [41].

Some fault plane solution diagrams of the studied earthquakes were plotted in Figure 1, and five predominant patterns can be classified. Similarly, Kao et al. [57] proposed five major seismogenic structures in the southernmost Ryukyu Arc-Taiwan region. They were (a) the Collision Seismic
Zone (CSZ, C type), associated with the relative plate convergence between the EP and the PSP along the Longitudinal Valley (e.g., Event 6), (b) the Interface Seismic Zone (ISZ, I type), related to a plate boundary between the EP and the PSP with low-angle thrust faulting to the north with a depth range of 10 to $30 \mathrm{~km}$ (e.g., Events 20, 21, 23, 24, and 27), (c) the Wadati-Benioff Seismic Zone (WBSZ, W type), indicating that the earthquakes deeper than $\sim 60 \mathrm{~km}$ occurred within the Wadati-Benioff zone striking east to west and extending westward beneath NE Taiwan (e.g., Events 7, 10, 11, and 12), (d) the Lateral Compression Seismic Zone (LCSZ, L type), related to a mixture of thrust and oblique strike-slip with $P$-axes in approximately an east-west direction, roughly parallel to the local strike of the trench-arc system thrust or 


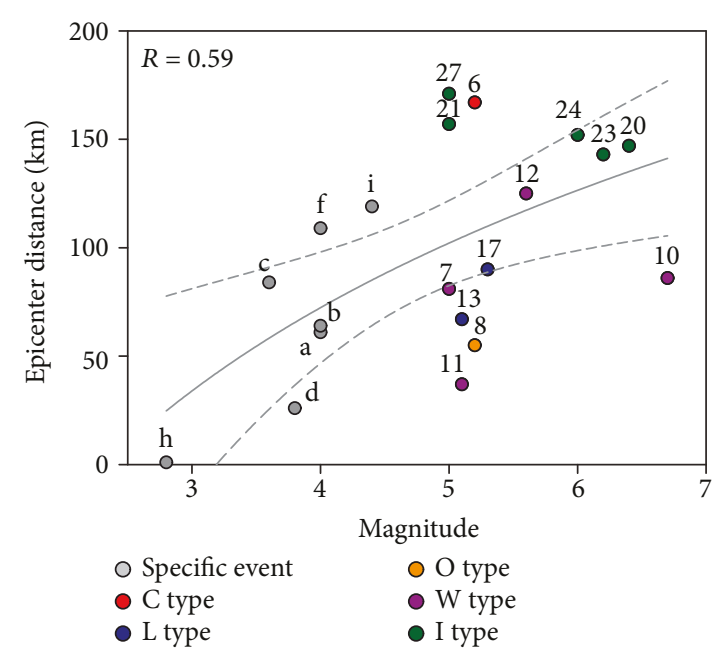

(a)

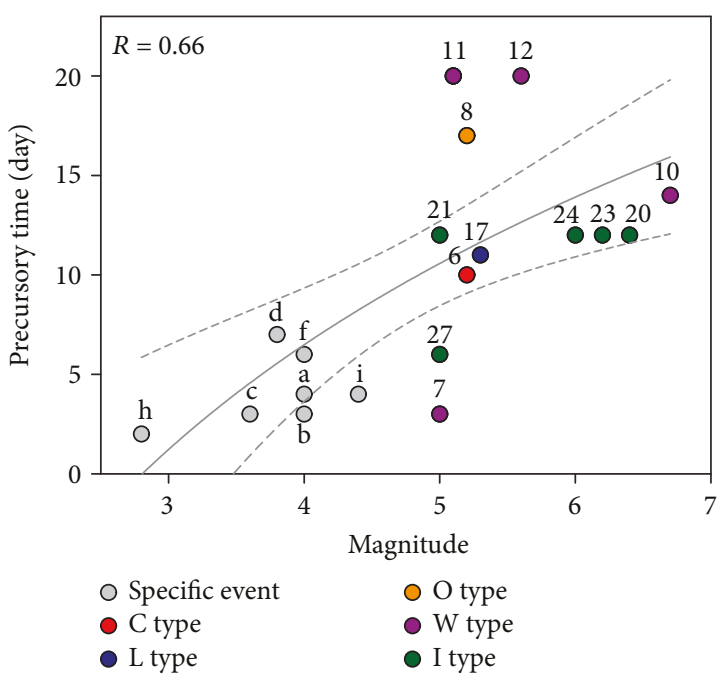

(b)

FIGURE 7: Variation diagrams showing the relationship between earthquake magnitude and (a) epicenter distance to the YMSG monitoring site and (b) distribution of the precursory time. Fitted curves are shown as solid lines. Dashed lines indicate the $95 \%$ confidence interval of the data set.

oblique-thrust faulting (e.g., Events 13 and 17), and (e) the Okinawa Seismic Zone (OSZ, O type), reflecting the gradual changing state of strain associated with the crustal deformation of the Okinawa opening with a characteristic of shallow earthquakes occurring (e.g., Event 8).

The dependent relationship between the epicenter distance to the YMSG site and the magnitude of the PE was shown in Figure $7(\mathrm{a})$. A good correlation $(R=0.66)$ was obtained between these variables. The best-fit line may be used to estimate the magnitude of an earthquake with a given epicenter distance. In other words, a larger magnitude of the PE might be distributed in greater epicenter distances of the YMSG station. As mentioned above, when the distance of the earthquake epicenter was farther than $180 \mathrm{~km}$, no anomaly was detected. And the distributions of the PE, including I type, $\mathrm{L}$ type, $\mathrm{O}$ type, $\mathrm{W}$ type, and specific events, get closer towards the YMSG station.
The good correlation between the magnitude of PE and precursory time $\left(\Delta T_{\text {Gamma }}\right)$ was presented in Figure $7(\mathrm{~b})$. The moderate correlation $(R=0.59)$ indicates that it is possible to forecast the magnitude of an impending earthquake. A longer precursory time of gamma ray anomalies appears to be associated with a larger upcoming earthquake, especially the occurrence of I type and $\mathrm{W}$ type with high probability. We also found that an anomaly of $C$ type was recorded in only one (Event 6 ) out of five events, suggesting that $C$ type may be not sensitive for the YMSG station but valuable for the TPT station (Table 2).

The YMSG station is located at the western end of the subduction system in the northern Taiwan area, where the PSP is subducting northward beneath the EP. Furthermore, this region is still seismically active due to continuous convergence and volcanic activity, with changes in highpressure fluid affected by a deeper pump system [58]. Some microcracks may be also developed during this process, causing the short duration gamma ray anomalies. Similarly, Padrón et al. [59] found that crustal deformation and fracturing during high seismic activity enhance the release of radiogenic helium produced in the crust. Lee et al. [23] reported a short-term negative anomaly of ${ }^{3} \mathrm{He} /{ }^{4} \mathrm{He}$ ratios, which indicated that the radiogenic gas release of crustal components affected the degassing system for the short term.

It may be suggested that due to continuous convergence, the preseismic slow slip may occur around the subduction zone before the event. The volumetric expansions of the EP around northern Taiwan then released the additional radiogenic gas from the crustal component. The increase in gamma rays can be attributed to the expansion around the YMSG that produced new fractures for gas and fluid migrations, potentially associated with the slow slip (e.g., Events $6,7,8,10,17,20,21,23,24$, and 27). A similar explanation of the preseismic slow slip before the Tohoku earthquake was illustrated by Orihara et al. [60].

Hence, based upon the above-mentioned points, the preliminary outline of anomalous data regarding relevant earthquakes can be concluded, which may be associated with the dynamics of the subduction process.

4.4. Relationship between the Tectonic Setting and the Mechanism for Anomalous Signals. The geodynamic setting of the arc-continent collision in Taiwan is well defined by the oblique collision between the PSP and the EP, with the former plate moving about $8 \mathrm{~cm} /$ year [1]. To the north of the island lies the Ryukyu subduction zone, which results from the subduction of the PSP beneath the EP. A schematic diagram of the proposed physical mechanism based on the anomalies in radon at TPT and changes in gamma rays at YMSG is shown in Figure 8. Stages 1 to 2 are considered to have occurred successively before the significant earthquake, which occurred along the subduction region. During Stage 1, the prestress caused by the northwestern movement of the PSP may be transmitted by collision with the Kuanyin High along the major decollement to trigger radon enhancements due to the development of microcracks below the TPT station, while no significant changes at the YMSG station occur during this stage. The description of the similar model for 

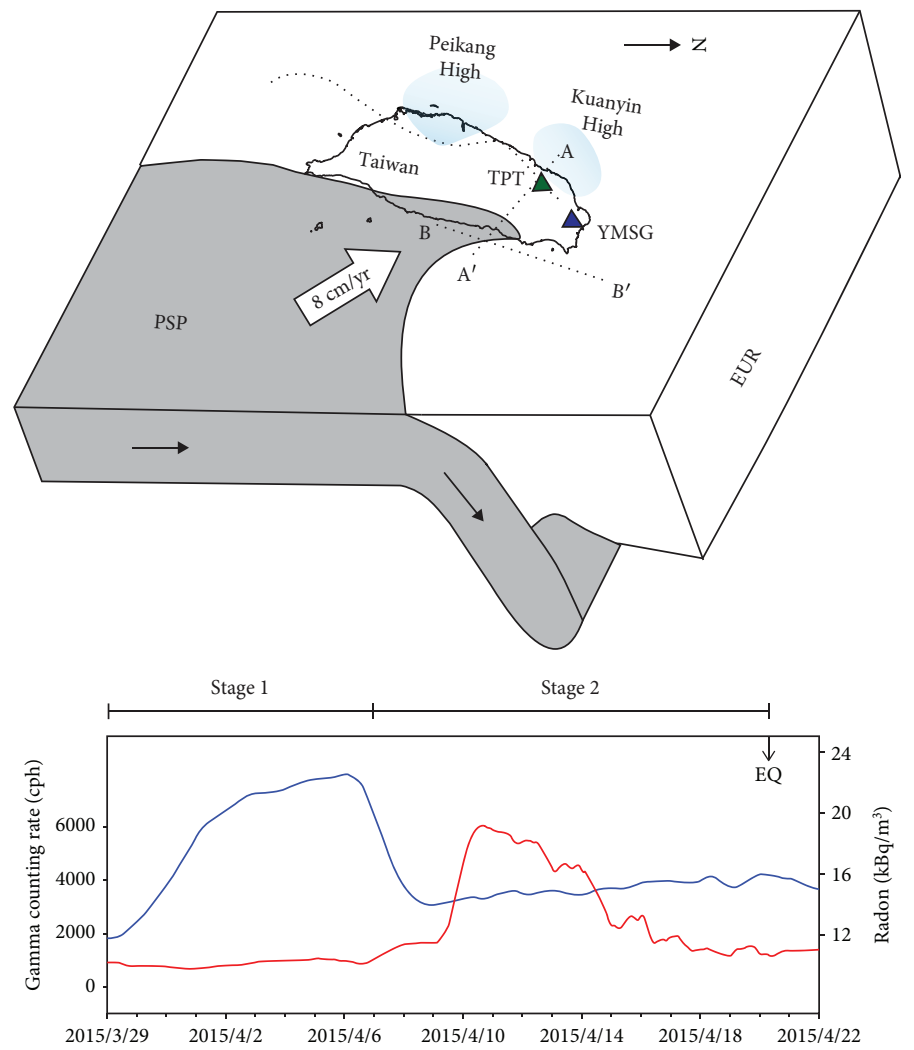

(a)
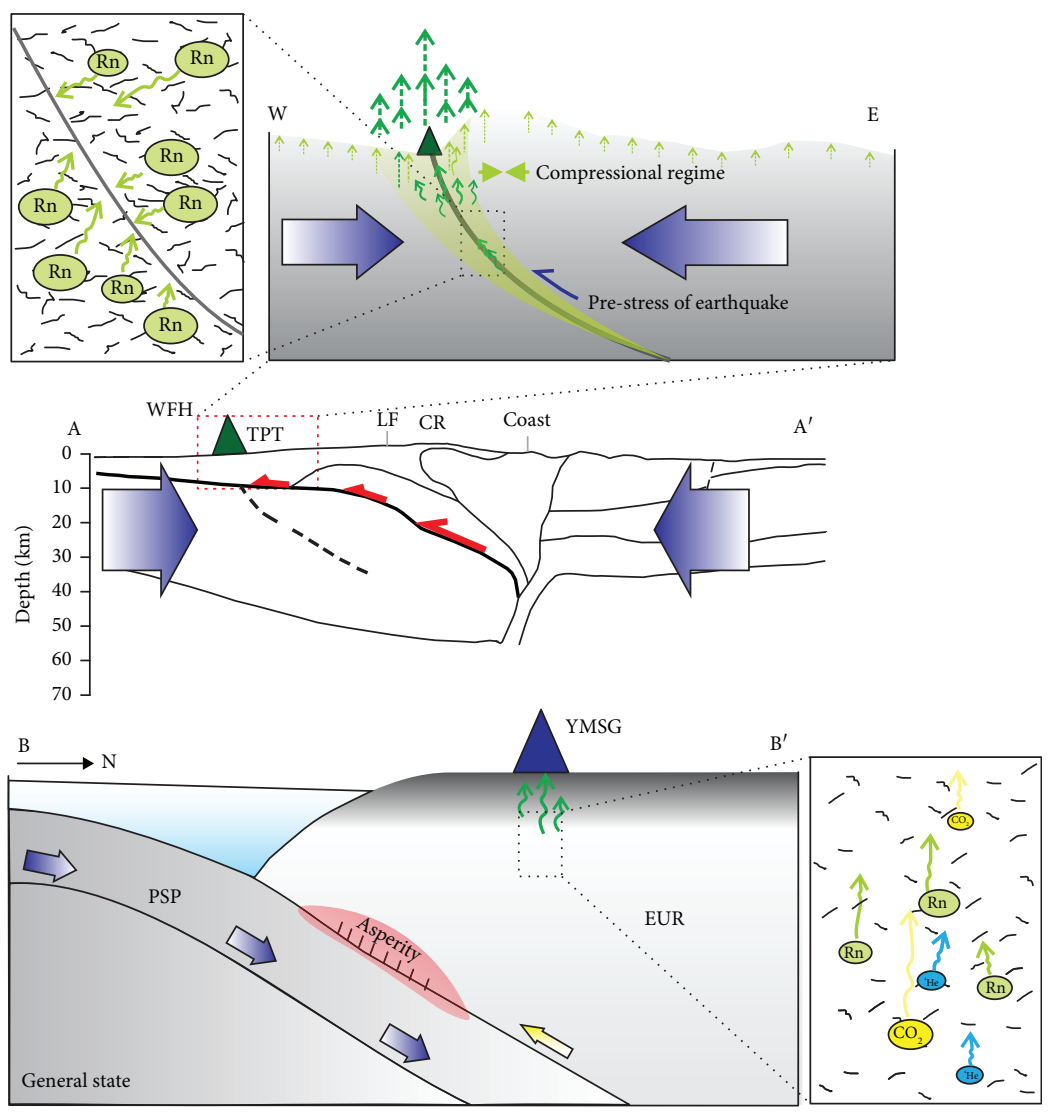

(b)

FIgURe 8: Continued. 

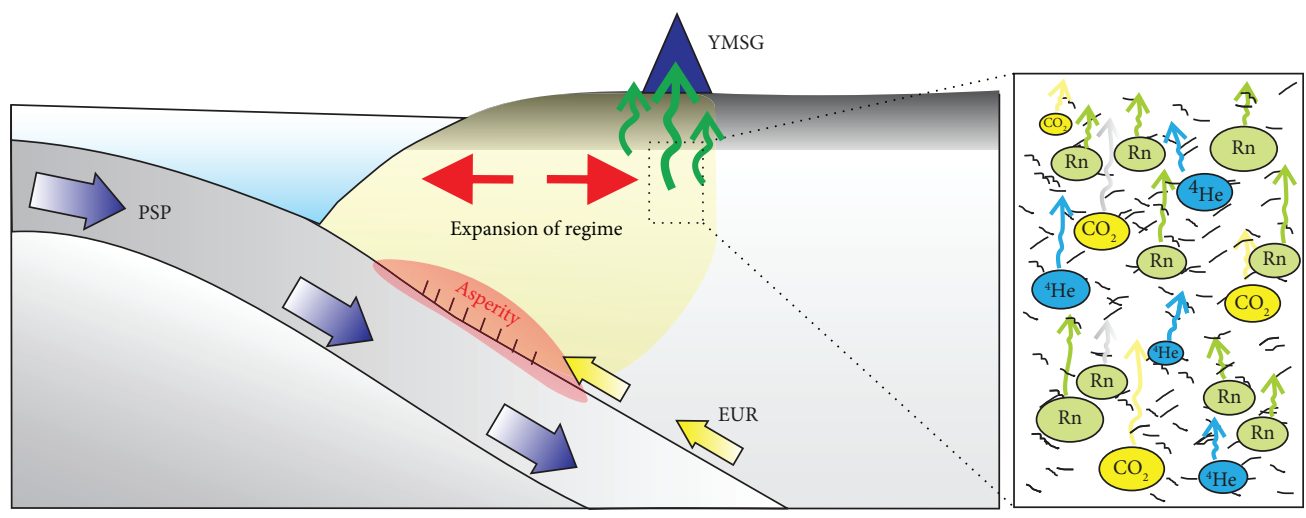

(c)

FIGURE 8: (a) A schematic diagram of the proposed physical mechanism based on the gamma ray anomaly of YMSG and radon anomaly at TPT. Stages 1 (b) and 2 (c) are considered to have occurred in order before the significant earthquakes. The schematic diagram showing a crustal-scale cross-section along the geophysical transect (AA' in (a)) modified by Fu et al. [41] is shown in (b).

TPT was described in detail by Fu et al. [41]. At Stage 2, further movement of the PSP may be locked by the EP and accumulated elastic stress results in the increase of radiogenic materials, such as gamma rays and radon gas, due to an increase in the porosity and fractures below the YMSG station.

Based on GPS observations, Rau et al. [61] and Ching et al. [62] concluded that crustal deformations showed the transition of surface strain in the type of tectonic activity from an arc-continent collision to a subduction/back-arc opening in northern Taiwan. Continental collision (around the TPT region) to extension (around the YMSG region) may be associated with the similar geodynamic process of stage 1 to stage 2 , respectively, at different time scales.

Therefore, anomalous signals from gamma rays and radon that are attributed to changes in pore pressure by the Coulomb stress changes may be attributed to near/farfield earthquakes or strain-induced changes in permeability within the preparation zone of the earthquake [63-65]. During the build-up of stress by preseismic activity, some of the existing features and the permeability of the fault zone are ruptured. The highly porous and permeable fault zones are then filled with gas and fluid. These closing and opening processes within the fault system are induced by the tectonic stress, which may be responsible for the episodic and/or periodic seismicity in northern and northeastern Taiwan.

\section{Conclusions}

The major findings of this study are listed below:

(1) Gamma ray variations are monitored at the YMSG monitoring station, located in the volcanic area of north Taiwan. Results of the temporal gamma ray variations are compared with meteorological records. The marginal effect of atmospheric parameters is observed in gamma ray measurements at the YMSG station

(2) Under continuous monitoring, many anomalously high radon values at TPT and gamma rays at YMSG were observed a few days to a few weeks before the seismic events

(3) Two groups of earthquakes can be identified at the YMSG station based on relevant earthquakes: earthquakes with shallower hypocenters and that are concentrated within $30 \mathrm{~km}$ of the monitoring station with a smaller magnitude and the earthquakes with deeper hypocenters and that are distributed at greater distances ( 30 to $180 \mathrm{~km})$ from the monitoring site

(4) The precursory changes in soil radon at the TPT station and gamma rays at the YMSG station may represent the preparation stage of an earthquake. When the observed precursory signals from these two stations with time delay occur, the possible impending large earthquake around the plate boundary in northeastern Taiwan can then be expected, which is located approximately between latitudes $23.9^{\circ} \mathrm{N}$ and $26.7^{\circ} \mathrm{N}$ and longitudes $121.3^{\circ} \mathrm{E}$ and $122.6^{\circ} \mathrm{E}$

(5) Both radon and gamma ray measurements provide a useful tool and act as a good indicator for exploring earthquake precursors, especially in north and northeastern Taiwan

\section{Data Availability}

The data used to support the findings of this study are available from the corresponding author upon request.

\section{Disclosure}

A preliminary study has been presented as a conference abstract in the 2005 AGU-Fall Meeting.

\section{Conflicts of Interest}

The authors declare that they have no conflicts of interest. 


\section{Acknowledgments}

We dedicate this paper to the late Prof. Tsanyao Frank Yang (TFY), who passed away on the 12th of March 2015. He had worked as a geochemist at the Department of Geosciences, National Taiwan University (NTU), Taiwan, for more than 20 years. His passion for research included setting new standards for relevant measurements, which enables us to present our work here. We thank Messrs. Shin-Jung Lin and KouWei $\mathrm{Wu}$ for helping in the operation and maintenance of the monitoring station. The research is supported by grants MOST 107-2116-M-002-019 through the Ministry of Science and Technology (MOST) and MOTC-CWB-106-E-01 from the Central Weather Bureau (CWB), Taiwan. The TEC contribution number for this article is 00151 . We would like to thank Uni-edit (http://www.uni-edit.net) for editing and proofreading this manuscript. We are also thankful to the editor Yunpeng Wang and the anonymous referee for their valuable comments and suggestions, which helped us to improve the manuscript.

\section{References}

[1] S. B. Yu, H. Y. Chen, and L. C. Kuo, "Velocity field of GPS stations in the Taiwan area," Tectonophysics, vol. 274, no. 1-3, pp. 41-59, 1997.

[2] L. S. Teng, "Extensional collapse of the northern Taiwan mountain belt," Geology, vol. 24, no. 10, pp. 949-952, 1996.

[3] K. L. Wang, S. L. Chung, C. H. Chen, R. Shinjo, T. F. Yang, and C. H. Chen, "Post-collisional magmatism around northern Taiwan and its relation with opening of the Okinawa Trough," Tectonophysics, vol. 308, no. 3, pp. 363-376, 1999.

[4] K. L. Wang, S. L. Chung, S. Y. O’Reilly, S. S. Sun, R. Shinjo, and C. H. Chen, "Geochemical constraints for the genesis of postcollisional magmatism and the geodynamic evolution of the northern Taiwan region," Journal of Petrology, vol. 45, no. 5, pp. 975-1011, 2004.

[5] W. S. Juang and J. C. Chen, "Geochronology and geochemistry of volcanic rocks in northern Taiwan," Bulletin of Central Geological Survey, vol. 5, pp. 31-66, 1989.

[6] S. R. Song, S. Tsao, and H. J. Lo, "Characteristics of the Tatun volcanic eruptions, North Taiwan: implications for a cauldron formation and volcanic evolution," Journal of the Geological Society of China, vol. 43, pp. 361-378, 2000.

[7] S. R. Song, T. F. Yang, Y. H. Yeh, S. Tsao, and H. J. Lo, "The Tatun volcano group is active or extinct?," Journal of the Geological Society of China, vol. 43, pp. 521-534, 2000.

[8] L. S. Teng, "Quaternary tectonics of Taiwan," Special Publication of the Central Geological Survey, vol. 18, pp. 1-24, 2007.

[9] S. J. Tsao, "Potassium-argon age determination of volcanic rocks from the Tatun Volcano Group," Bulletin of Central Geological Survey, vol. 9, pp. 137-154, 1994.

[10] W. H. Wang and C. H. Chen, "The volcanology and fission track age dating of pyroclastic deposits in Tatun Volcano Group," Acta Geologica Taiwanica, vol. 28, pp. 1-30, 1990.

[11] W. S. Juang, "Diversity and origin of quaternary basaltic magma series in northern Taiwan," Bulletin of the National Museum of Natural Science, vol. 4, pp. 125-165, 1993.
[12] C. H. Chen and J. J. S. Shen, "A refined historical record of volcanic eruptions around Taiwan: tectonic implications in the arc-continent collision area," Terrestrial, Atmospheric and Oceanic Sciences, vol. 16, no. 2, pp. 331-343, 2005.

[13] T. F. Yang, " $3 \mathrm{He} /{ }^{4} \mathrm{He}$ ratios of fumaroles and bubbling gases of hot springs in Tatun Volcano Group, North Taiwan," Journal of National Park, vol. 10, no. 1, pp. 73-94, 2000.

[14] T. F. Yang, Y. Sano, and S. R. Song, " ${ }^{3} \mathrm{He} /{ }^{4} \mathrm{He}$ ratios of fumaroles and bubbling gases of hot springs in Tatun Volcano Group, North Taiwan," Nuovo Cimento della Societa Italiana di Fisica C, vol. 22, pp. 281-286, 1999.

[15] T. Ohba, T. Sawa, N. Taira et al., "Magmatic fluids of Tatun volcanic group, Taiwan," Applied Geochemistry, vol. 25, no. 4, pp. 513-523, 2010.

[16] K. I. Konstantinou, C. H. Lin, and W. T. Liang, "Seismicity characteristics of a potentially active Quaternary volcano: the Tatun Volcano Group, northern Taiwan," Journal of Volcanology and Geothermal Research, vol. 160, no. 3-4, pp. 300-318, 2007.

[17] S. Wen, Y. Z. Chang, C. H. Chen, Y. G. Chen, and T. L. Teng, "The seismic velocity and attenuation structure beneath the Tatun volcanic area, Taiwan," Journal of Asian Earth Sciences, vol. 54-55, pp. 182-191, 2012.

[18] C. H. Lin, "Evidence for a magma reservoir beneath the Taipei metropolis of Taiwan from both S-wave shadows and P-wave delays," Scientific Reports, vol. 6, no. 1, article 39500, 2016.

[19] A. Kumar, V. Walia, Y. C. Sung, S. J. Lin, C. C. Fu, and K. L. Wen, "Soil gas survey in and around Shanchiao fault of northern Taiwan for establishing continuous monitoring station," Acta Geophysica, vol. 66, no. 5, pp. 1213-1221, 2018.

[20] A. Kumar, V. Walia, Y. C. Sung et al., "Integrated radon monitoring in Tatun Volcanic Areas of Northern Taiwan," Terrestrial, Atmospheric and Oceanic Sciences, vol. 29, no. 3, pp. 261273, 2018.

[21] T. F. Lan, T. F. Yang, H. F. Lee et al., "Compositions and flux of soil gas in Liu-Huang-Ku hydrothermal area, northern Taiwan," Journal of Volcanology and Geothermal Research, vol. 165, no. 1-2, pp. 32-45, 2007.

[22] H. F. Lee, T. F. Yang, T. F. Lan, S. R. Song, and S. Tsao, "Fumarolic gas composition of the Tatun Volcano Group, northern Taiwan," Terrestrial, Atmospheric and Oceanic Sciences, vol. 16, no. 4, pp. 843-864, 2005.

[23] H. F. Lee, T. F. Yang, T. F. Lan, C. H. Chen, S. R. Song, and S. Tsao, "Temporal variations of gas compositions of fumaroles in the Tatun Volcano Group, northern Taiwan," Journal of Volcanology and Geothermal Research, vol. 178, no. 4, pp. 624-635, 2008.

[24] C. M. Liu, S. R. Song, Y. L. Chen, and S. Tsao, "Characteristics and origins of hot springs in the Tatun Volcano Group in northern Taiwan," Terrestrial, Atmospheric and Oceanic Sciences, vol. 22, no. 5, pp. 475-489, 2011.

[25] H. Wen, T. F. Yang, T. F. Lan et al., "Soil $\mathrm{CO}_{2}$ flux in hydrothermal areas of the Tatun Volcano Group, Northern Taiwan," Journal of Volcanology and Geothermal Research, vol. 321, pp. 114-124, 2016.

[26] M. L. I. Witt, T. P. Fischer, D. M. Pyle, T. F. Yang, and G. F. Zellmer, "Fumarole compositions and mercury emissions from the Tatun volcanic field, Taiwan: results from multicomponent gas analyser, portable mercury spectrometer and direct sampling techniques," Journal of Volcanology and Geothermal Research, vol. 178, no. 4, pp. 636-643, 2008. 
[27] T. F. Yang, H. Y. Wen, C. C. Fu et al., "Soil radon flux and concentrations in hydrothermal area of the Tatun volcano group, Northern Taiwan," Geochemical Journal, vol. 45, no. 6, pp. 483-490, 2011.

[28] K. I. Konstantinou, C. H. Lin, W. T. Liang, and Y. C. Chan, "Seismogenic stress field beneath the Tatun Volcano Group, northern Taiwan," Journal of Volcanology and Geothermal Research, vol. 187, no. 3-4, pp. 261-271, 2009.

[29] C. H. Lin, K. I. Konstantinou, W. T. Liang et al., "Preliminary analysis of volcanoseismic signals recorded at the Tatun Volcano Group, northern Taiwan," Geophysical Research Letters, vol. 32, no. 10, article L10313, 2005.

[30] C. H. Lin, K. I. Konstantinou, H. C. Pu et al., "Preliminary results from seismic monitoring at the Tatun volcanic area of northern Taiwan," Terrestrial, Atmospheric and Oceanic Sciences, vol. 16, no. 3, pp. 563-577, 2005.

[31] M. Murase, C. H. Lin, F. Kimata, H. Mori, and H. C. Pu, "Volcano-hydrothermal activity detected by precise levelling surveys at the Tatun volcano group in Northern Taiwan during 2006-2013," Journal of Volcanology and Geothermal Research, vol. 286, pp. 30-40, 2014.

[32] H. C. Pu, C. H. Lin, Y. C. Huang et al., "The volcanic earthquake swarm of October 20, 2009 in the Tatun area of northern Taiwan," Terrestrial, Atmospheric and Oceanic Sciences, vol. 25, no. 5, pp. 625-635, 2014.

[33] J. B. H. Shyu, K. Sieh, Y. G. Chen, and C. S. Liu, "Neotectonic architecture of Taiwan and its implications for future large earthquakes," Journal of Geophysical Research, vol. 110, no. B8, article B08402, 2005.

[34] S. Giammanco, K. W. W. Sims, and M. Neri, "Measurements of ${ }^{220} \mathrm{Rn}$ and ${ }^{222} \mathrm{Rn}$ and $\mathrm{CO}_{2}$ emissions in soil and fumarole gases on Mt. Etna volcano (Italy): implications for gas transport and shallow ground fracture," Geochemistry, Geophysics, Geosystems, vol. 8, no. 10, article Q10001, 2007.

[35] M. Neri, B. Behncke, M. Burton et al., "Continuous soil radon monitoring during the July 2006 Etna eruption," Geophysical Research Letters, vol. 33, no. 24, article L24316, 2006.

[36] M. Neri, E. Ferrera, S. Giammanco et al., "Soil radon measurements as a potential tracer of tectonic and volcanic activity," Scientific Reports, vol. 6, no. 1, article 24581, 2016.

[37] N. M. Pérez, J. M. L. Salazar, P. A. Hernández, T. Soriano, K. Lopez, and K. Notsu, "Diffuse $\mathrm{CO}_{2}$ and ${ }^{222} \mathrm{Rn}$ degassing from San Salvador volcano, El Salvador, Central America," in Natural Hazards in El Salvador, W. I. Rose, J. J. Bommer, D. L. López, M. J. Carr, and J. J. Major, Eds., vol. 375, pp. 227236, Bulletin of Geological Society of America, 2004.

[38] J. M. L. Salazar, N. M. Pérez, P. A. Hernández et al., "Precursory diffuse carbon dioxide degassing signature related to a 5.1 magnitude earthquake in El Salvador, Central America," Earth and Planetary Science Letters, vol. 205, no. 1-2, pp. 8189,2002

[39] C. C. Fu, P. K. Wang, L. C. Lee et al., "Temporal variation of gamma rays as a possible precursor of earthquake in the Longitudinal Valley of eastern Taiwan," Journal of Asian Earth Sciences, vol. 114, no. 2, pp. 362-372, 2015.

[40] G. Giuliani, A. Attanasio, and G. Fioravanti, "Gamma detectors for continuous monitoring of radon," International Environmental Application and Science, vol. 8, no. 4, pp. 541-550, 2013.

[41] C. C. Fu, T. F. Yang, C. H. Chen et al., "Spatial and temporal anomalies of soil gas in northern Taiwan and its tectonic and seismic implications," Journal of Asian Earth Sciences, vol. 149, pp. 64-77, 2017.

[42] T. Ichiji and T. Hattori, "Continuous measurement of environmental gamma-ray radiation in Tokyo using Ge semiconductor detector," Proceedings of the IRPA 11 Conference, 2000P$4 a-288$.

[43] A. Melintescu, S. Chambers, J. Crawford, A. Williams, B. Zorila, and D. Galeriu, "Radon-222 related influence on ambient gamma dose," Journal of Environmental Radioactivity, vol. 189, pp. 67-78, 2018.

[44] M. Takeyasu, T. Iida, T. Tsujimoto, K. Yamasaki, and Y. Ogawa, "Concentrations and their ratio of ${ }^{222} \mathrm{Rn}$ decay products in rainwater measured by gamma-ray spectrometry using a low-background Ge detector," Journal of Environmental Radioactivity, vol. 88, no. 1, pp. 74-89, 2006.

[45] T. Tsvetkova, I. Nevinsky, and V. Nevinsky, "Results of spectral monitoring of environmental gamma background in a fault zone of the Western Caucasus for seismological application," Radiation Measurements, vol. 69, pp. 35-49, 2014.

[46] H. Yamanisi and H. Miyake, "Separation of natural background by using correlation of time-series data on radiation monitoring," Journal of Nuclear Science and Technology, vol. 40, no. 1, pp. 44-48, 2003.

[47] J. L. Burnett, I. W. Croudace, and P. E. Warwick, "Short-lived variations in the background gamma-radiation dose," Journal of Radiological Protection, vol. 30, no. 3, pp. 525-533, 2010.

[48] R. Livesay, C. S. Blessinger, T. Guzzardo, and P. Hausladen, "Rain-induced increase in background radiation detected by Radiation Portal Monitors," Journal of Environmental Radioactivity, vol. 137, pp. 137-141, 2014.

[49] J. F. Mercier, B. L. Tracy, R. d'Armours et al., "Increased environmental gamma-ray dose rate during precipitation: a strong correlation with contributing air mass," Journal of Environmental Radioactivity, vol. 100, no. 7, pp. 527-533, 2009.

[50] C. C. Fu, T. F. Yang, V. Walia et al., "Variations of soil-gas composition around the active Chihshang Fault in a plate suture zone, eastern Taiwan," Radiation Measurements, vol. 44, no. 9-10, pp. 940-944, 2009.

[51] Y. H. Oh and G. Kim, "A radon-thoron isotope pair as a reliable earthquake precursor," Scientific Reports, vol. 5, no. 1, article 13084, 2015.

[52] R. C. Ramola, Y. Prasad, G. Prasad, S. Kumar, and V. M. Choubey, "Soil-gas radon as seismotectonic indicator in Garhwal Himalaya," Applied Radiation and Isotopes, vol. 66, no. 10, pp. 1523-1530, 2008.

[53] Y. M. Wu, C. H. Chang, L. Zhao et al., "Seismic tomography of Taiwan: improved constraints from a dense network of strong motion stations," Journal of Geophysical Research, vol. 112, no. B8, article B08312, 2007.

[54] J. Y. Lin, S. K. Hsu, and J. C. Sibuet, "Melting features along the western Ryukyu slab edge (northeast Taiwan): tomographic evidence," Journal of Geophysical Research, vol. 109, no. B12, article B12402, 2004.

[55] J. Malavieille, "Impact of erosion, sedimentation, and structural heritage on the structure and kinematics of orogenic wedges: analog models and case studies," GSA Today, vol. 20, pp. 4-10, 2010.

[56] J. Suppe, "Mechanics of mountain building and metamorphism in Taiwan," Memoir of the Geological Society of China, vol. 4, pp. 67-89, 1981. 
[57] H. Kao, S. J. Shen, and K. F. Ma, "Transition from oblique subduction to collision: earthquakes in the southernmost Ryukyu arc-Taiwan region," Journal of Geophysical Research, vol. 103, no. B4, pp. 7211-7229, 1998.

[58] C. H. Lin and H. C. Pu, "Very-long-period seismic signals at the Tatun Volcano Group, northern Taiwan," Journal of Volcanology and Geothermal Research, vol. 328, pp. 230236, 2016.

[59] E. Padrón, N. M. Pérez, P. A. Hernández et al., "Diffusive helium emissions as a precursory sign of volcanic unrest," Geology, vol. 41, no. 5, pp. 539-542, 2013.

[60] Y. Orihara, M. Kamogawa, and T. Nagao, "Preseismic changes of the level and temperature of confined groundwater related to the 2011 Tohoku Earthquake," Scientific Reports, vol. 4, no. 1, article 6907, 2014.

[61] R. J. Rau, K. E. Ching, J. C. Hu, and J. C. Lee, "Crustal deformation and block kinematics in transition from collision to subduction: global positioning system measurements in northern Taiwan, 1995-2005," Journal of Geophysical Research, vol. 113, no. B9, article B09404, 2008.

[62] K. E. Ching, M. L. Hsieh, K. M. Johnson, K. H. Chen, R. J. Rau, and M. Yang, "Modern vertical deformation rates and mountain building in Taiwan from precise leveling and continuous GPS observations, 2000-2008," Journal of Geophysical Research, vol. 116, no. B8, article B08406, 2011.

[63] I. P. Dobrovolsky, S. I. Zubkov, and V. I. Miachkin, "Estimation of the size of earthquake preparation zone," Pure and Applied Geophysics, vol. 117, no. 5, pp. 1025-1044, 1979.

[64] R. L. Fleischer, "Dislocation model for radon response to distant earthquakes," Geophysical Research Letters, vol. 8, no. 5, pp. 477-480, 1981.

[65] P. Upton, P. O. Koons, and D. Eberhart-Phillips, "Extension and partitioning in an oblique subduction zone, New Zealand: constraints from three-dimensional numerical modeling," Tectonics, vol. 22, no. 6, article 1068, 2003.

[66] C. W. Lin, W. C. Chang, S. T. Lu, T. S. Shih, and W. C. Huang, "An introduction to the active faults of Taiwan, 2nd edition, explanatory text of the active fault map of Taiwan," in Special Publication of the Central Geological Survey, vol. 13, pp. 1-122, 2000. 

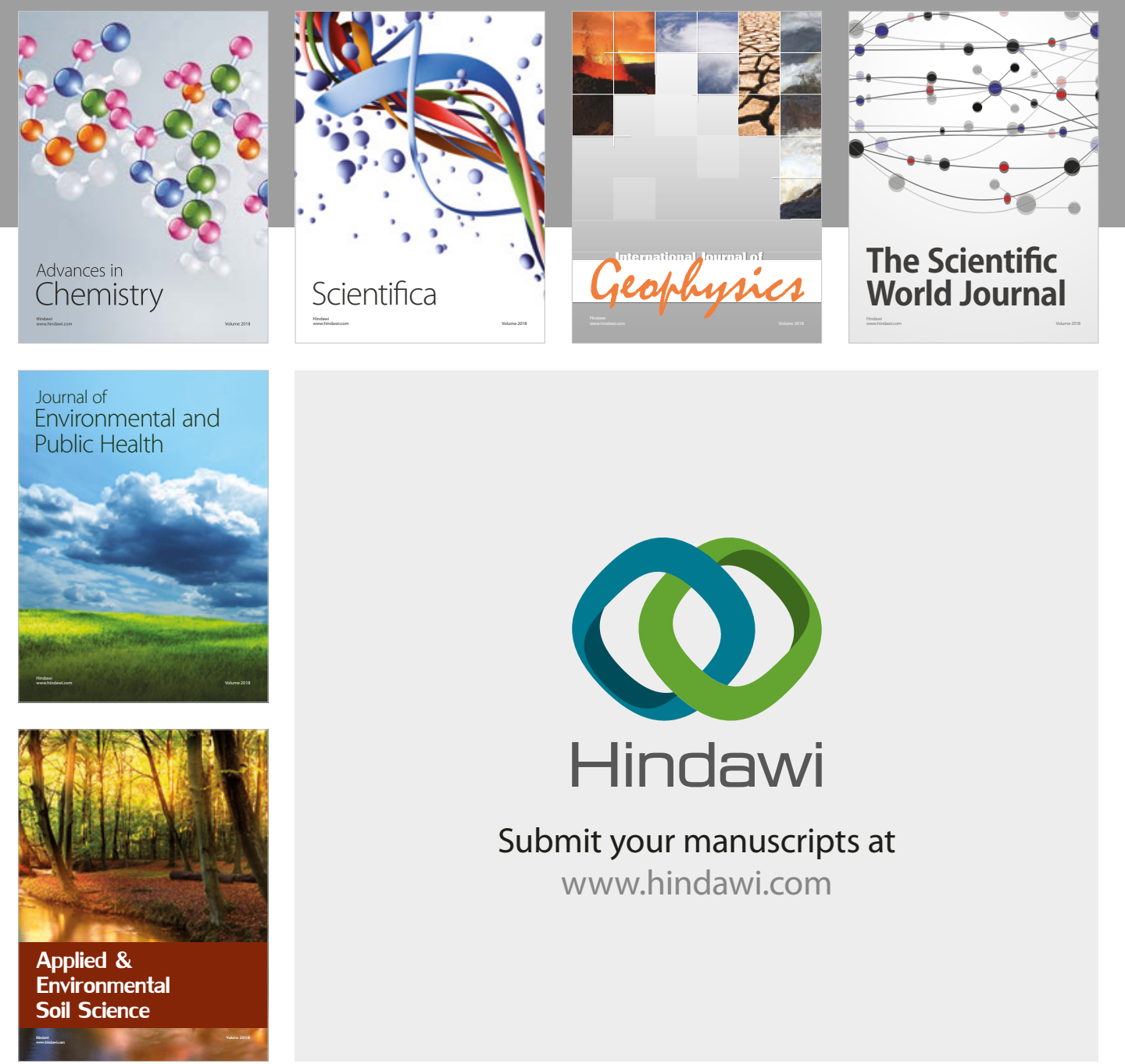

The Scientific

\section{World Journal}
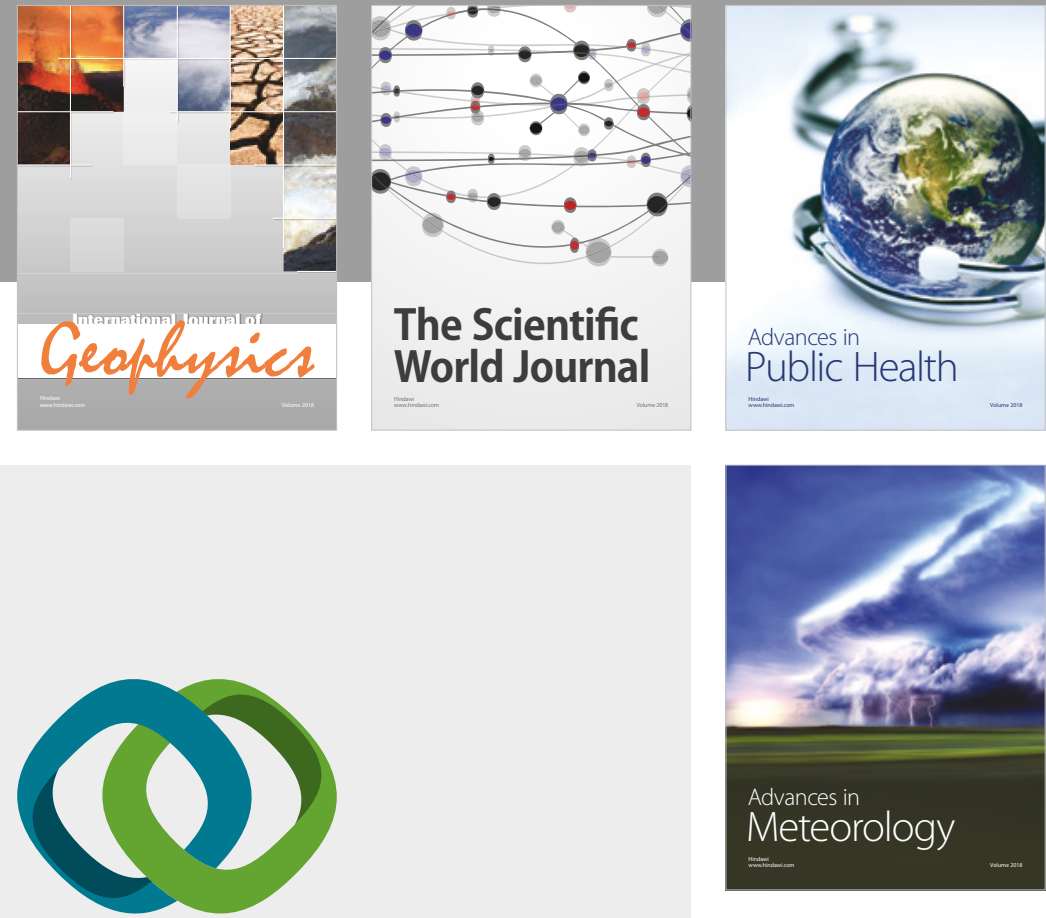

Advan

Public Health

\section{Hindawi}

Submit your manuscripts at

www.hindawi.com
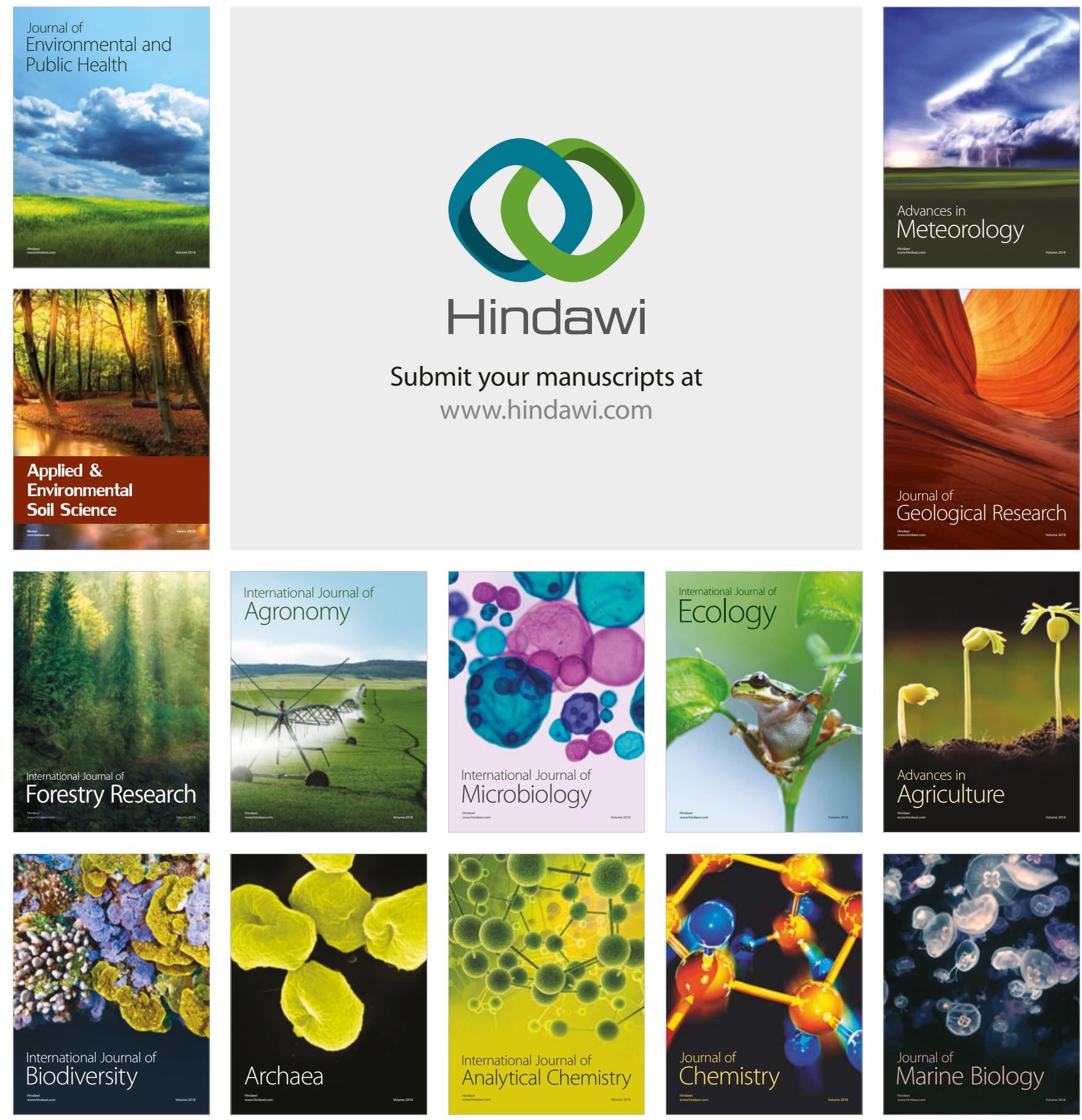